\title{
PENGARUH ATMOSFER TOKO, LOKASI DAN KERAGAMAN PRODUK TERHADAP KEPUTUSAN PEMBELIAN KONSUMEN PADA PLANET BAN MARGONDA RAYA, DEPOK
}

\author{
Rachmat Hidayat ${ }^{1}$ \\ Atsari Sujud ${ }^{2}$ \\ ${ }^{1,2}$ Fakultas Ekonomi dan Bisnis Universitas Nasional \\ Email: $\underline{\text { RachmattHidayattt@gmail.com }}{ }^{1}, \underline{\text { atsari.sujud@gmail.com }}{ }^{2}$
}

\begin{abstract}
ABSTRAK
Penelitian ini bertujuan untuk menganalisis pengaruh atmosfer toko, lokasi dan keragaman produk terhadap keputusan pembelian pada Planet Ban Margonda Raya, Depok. Populasi penelitian yang digunakan adalah pengguna jasa di Planet Ban Margonda Raya, Depok. Pengambilan sampel dilakukan dengan menggunakan metode accidental sampling dengan jumlah sampel sebanyak 100 responden. Analisis dilakukan dengan menggunakan regresi linear berganda. Hasil penelitian menunjukkan bahwa atmosfer toko, lokasi dan keragaman produk secara parsial berpengaruh positif dan signifikan terhadap keputusan pembelian pada Planet Ban Margonda Raya, Depok.
\end{abstract}

Kata kunci: Atmosfer toko, lokasi, keragaman produk, keputusan pembelian

\section{ABSTRACT}

This research aims to analyze the effect of atmosphere store, location and product diversity on purchasing decision in Planet Ban Margonda Raya, Depok. The population of the research used was service users in Planet Ban Margonda Raya, Depok. Sampling was done using accidental sampling method with 100 respondents amount of sample. Analysis was done using multiple linear regression. The results of the study showed that store atmosphere, location and product diversity partially has positive and significant effect on purchasing decision in Planet Ban Margonda Raya, Depok.

Keywords: Atmosphere store, location, product diversity, decisions purchase

\section{PENDAHULUAN}

Industri sepeda motor mengalami pertumbuhan yang pesat setiap tahunnya karena terus meningkatnya kebutuhan masyarakat terhadap sarana transportasi. Asosiasi Industri Sepeda Motor Indonesia mencatat bahwa distribusi sepeda motor di Indonesia mencapai 5.886.103 unit di tahun 2017. Dalam rangka mengimbangi permintaan masyarakat terhadap sepeda motor, Planet Ban hadir untuk mengimbangi kebutuhan masyarakat terhadap suku cadang otomotif roda dua.

Planet Ban merupakan toko suku cadang otomotif roda dua yang memiliki lebih dari 500 outlet dengan produk utama berupa ban motor (Planet Ban, 2018). Pada tahun 2016-2017, Planet Ban meraih penghargaan Top Brand selama dua tahun berturut-turut (Top Brand Award, 2018). Meskipun demikian, data yang berasal dari pihak internal 
menunjukkan bahwa omzet penjualan yang diperoleh Planet Ban mengalami trend yang menurun di sepanjang periode 2014-2017. Hal ini menunjukkan bahwa keputusan pembelian yang diambil oleh konsumen terhadap produk yang ditawarkan oleh Planet Ban juga mengalami penurunan selama periode tersebut. Dalam rangka menghindari terjadinya penurunan omzet penjualan yang berkelanjutan di masa mendatang, perlu dilakukan penelitian terhadap faktor-faktor yang kemungkinan menjadi penyebab dari penurunan keputusan pembelian tersebut.

Salah satu faktor yang berpengaruh terhadap keputusan pembelian adalah atmosfer toko. Hal tersebut dibuktikan oleh temuan Hanafitrah dan Widiartanto (2018) yang menunjukkan bahwa atmosfer toko memberikan pengaruh yang positif dan signifikan terhadap keputusan pembelian. Artinya, semakin baik atmosfer yang tercipta di suatu toko, maka semakin tinggi keputusan pembelian yang dilakukan terhadap produk yang ditawarkan di toko tersebut. Sebaliknya, semakin buruk atmosfer yang tercipta di suatu toko, maka semakin rendah keputusan pembelian yang dilakukan terhadap produk yang ditawarkan di toko tersebut. Sejalan dengan hal tersebut, Utami (2010) mengemukakan bahwa atmosfer toko memang ditujukan untuk merancang tanggapan emosional dan persepsi pelanggan, serta mempengaruhi pelanggan untuk membeli barang.

Keputusan pembelian juga dapat dipengaruhi oleh faktor lokasi. Hal tersebut didasari oleh hasil penelitian yang dilakukan oleh Lisdayanti (2017) dan Antari, dkk. (2014) yang membuktikan bahwa lokasi berpengaruh positif dan signifikan terhadap keputusan pembelian. Hal tersebut menunjukkan bahwa semakin strategis lokasi suatu toko, maka semakin tinggi keputusan pembelian yang dilakukan terhadap produk yang ditawarkan di toko tersebut. Sebaliknya, semakin tidak strategis lokasi suatu toko, maka semakin rendah keputusan pembelian yang dilakukan terhadap produk yang ditawarkan di toko tersebut. Sejalan dengan hal tersebut, Suwarman (2011) mengemukakan bahwa lokasi akan memberikan pengaruh yang besar terhadap keinginan konsumen untuk datang dan berbelanja di suatu toko.

Faktor lain yang dapat mempengaruhi keputusan pembelian adalah keragaman produk. Ogi, dkk. (2018) serta Prambudi dan Rachmi (2017) membuktikan bahwa keragaman produk berpengaruh positif dan signifikan terhadap keputusan pembelian. Hal tersebut menunjukkan bahwa semakin tinggi tingkat keragaman produk yang ditawarkan di suatu toko, maka semakin tinggi pula tingkat keputusan pembelian yang dilakukan terhadap produk yang ditawarkan di toko tersebut. Sebaliknya, semakin rendah tingkat 
keragaman produk yang ditawarkan di suatu toko, maka semakin rendah pula tingkat keputusan pembelian yang dilakukan terhadap produk yang ditawarkan di toko tersebut.

Berdasarkan latar belakang di atas, perlu dilakukan penelitian untuk menganalisis pengaruh atmosfer toko, lokasi dan keragaman produk terhadap keputusan pembelian konsumen pada Planet Ban, khusunya di outlet yang berlokasi di Magonda Raya, Depok. Apabila ketiga variabel tersebut terbukti dapat secara signifikan mempengaruhi keputusan pembelian, maka Planet Ban dapat menggunakannya sebagai alat untuk meningkatkan keputusan pembelian terhadap produk-produk yang ditawarkan olehnya.

\section{TINJAUAN PUSTAKA}

\section{Keputusan pembelian}

Menurut Schiffman dan Kanuk (2008:547), keputusan pembelian adalah suatu pemilihan dari dua atau lebih alternatif pembelian yang tersedia. Kotler dan Armstrong (2008:181) mendefinisikan keputusan pembelian konsumen sebagai pembelian terhadap merek yang paling disukai dari beberapa alternatif yang tersedia.

Menurut Kotler dan Keller (2009:184), konsumen melalui tiga tahap dalam proses keputusan pembelian, yaitu sebagai berikut.

1. Evaluasi alternatif

Kotler dan Keller (2009:186) mengemukakan tiga konsep yang dapat digunakan untuk memahami proses evaluasi, yaitu: (a) konsumen berupaya untuk memuaskan kebutuhannya; (b) konsumen mencari suatu manfaat tertentu dari produk; dan (c) konsumen melihat masing-masing produk sebagai sekelompok atribut dengan berbagai kemampuan untuk menghantarkan manfaat yang diperlukan untuk memuaskan kebutuhan.

\section{Keputusan pembelian}

Dalam keputusan pembelian, konsumen membentuk maksud untuk membeli merek yang paling disukai yang pelaksanaannya dapat dibentuk dengan lima subkeputusan pembelian, yaitu merek, distributor, kuantitas, waktu, dan cara pembayaran (Kotler dan Keller, 2009:188).

3. Perilaku pasca pembelian

Pasca pembelian, konsumen mungkin mengalami konflik tertentu karena melihat adanya fitur tertentu yang mengkhawatirkan atau mendengar hal-hal tertentu yang menyenangkan mengenai merek lain yang membuatnya menjadi waspada terhadap informasi yang mendukung keputusannya. Dalam hal ini, komunikasi pemasaran 
diperlukan untuk meyakinkan konsumen terhadap pilihannya dan membuatnya merasa nyaman dengan merek yang dimaksud (Kotler dan Keller, 2009:190).

\section{Atmosfer Toko}

Menurut Utami (2010), atmosfer toko adalah suatu kombinasi yang terdiri dari karakteristik fisik, seperti arsitektur, tata letak, pencahayaan, warna, temperatur, musik, dan aroma yang ditujukan untuk merancang tanggapan emosional dan persepsi pelanggan, serta mempengaruhi pelanggan untuk membeli barang. Atmosfer toko berhubungan dengan cara manajer dalam memanipulasi desain bangunan, ruang interior, layout lorong, tekstur karpet dan dinding, bau, warna, bentuk, serta suara yang dialami oleh para pelanggan yang keseluruhannya ditujukan untuk menciptakan suatu pengaruh tertentu (Mowen dan Minor, 2002:139).

Menurut Mowen dan Minor (2002:139), atmosfer toko terdiri dari beberapa elemen, yaitu sebagai berikut.

\section{Layout}

Layout dirancang untuk memudahkan pergerakan pelanggan, membantu retailer untuk menyajikan barang dagangan mereka dan menciptakan suasana tertentu yang dapat mempengaruhi reaksi konsumen dan perilaku pembelian (Mowen dan Minor, 2002:139).

2. Musik

Menurut Bruner (1990), musik merupakan salah satu dimensi dari servicescape yang merupakan faktor penentu utama dari evaluasi terhadap suatu pelayanan.

3. Aroma

Mowen dan Minor (2002:140), para pembelanja cenderung sering kembali ke toko yang diberi wewangian dan menganggap bahwa barang-barang yang ditawarkan di toko tersebut memiliki kualitas yang lebih baik daripada barang-barang yang ditawarkan di toko yang tidak diberi wewangian.

4. Tekstur

Dengan pengolahan tekstur dari bahan yang baik, layout eksterior dari suatu toko akan memberikan kesan dan kualitas yang lebih menarik dalam mempengaruhi visitor untuk melakukan pembelian. 
5. Desain bangunan

Desain bangunan dan koridor di mal dan toko-toko secara langsung dapat mempengaruhi pergerakan konsumen tanpa perilaku yang dipengaruhi oleh keyakinan atau perasaan terlebih dahulu (Mowen dan Minor, 2002:140).

Menurut Berman dan Evans (2004), atmosfer toko memiliki indikator sebagai berikut.

1. Bagian luar toko (exterior)

Eksterior toko akan mempengaruhi citra toko. Elemen dari eksterior itu sendiri meliputi bagian muka toko, simbol, pintu, tampilan jendela, tinggi dan ukuran gedung, keunikan, lingkungan sekitar, serta tempat parkir.

2. Bagian dalam toko (general interior)

Dalam hal ini, hal yang pelru diperhatikan adalah display di dalam toko. Desain interior toko perlu dirancang untuk memaksimalkan visual merchandising yang dapat menarik perhatian visitor dan memudahkan mereka dalam mengamati, memeriksa dan memilih barang.

3. Tata letak toko (store layout)

Dalam hal ini, perlu dirancang penentuan lokasi dan fasilitas toko yang baik dengan memanfaatkan ruangan toko seefektif mungkin.

4. Display bagian dalam (interior display)

Penataan interior display ditujukan untuk menyampaikan informasi kepada konsumen dan membentuk atmosfer toko yang baik.

\section{Lokasi}

Menurut Alma (2003:103), lokasi merupakan tempat suatu perusahaan beroperasi atau melakukan kegiatannya untuk menghasilkan barang/jasa dengan memperhatikan aspek ekonominya. Suwarman (2011) mendefinisikan lokasi sebagai tempat usaha yang sangat berpengaruh terhadap keinginan konsumen untuk datang dan berbelanja. Menurut Alma (2003:105), pemilihan lokasi usaha yang tepat akan menentukan keberhasilan usaha di masa mendatang.

Menurut Tjiptono (2009:190), pemilihan lokasi perlu mempertimbangkan indikator-indikator berikut.

1. Akses, yakni meliputi keterjangkauan lokasi dan sarana transportasi umum.

2. Visibilitas, yakni seberapa jelas lokasi dapat dilihat dari jarak pandang yang normal. 
3. Lalu lintas (traffic), yakni indikator yang meliputi dua pertimbangan, yaitu: (a) banyaknya orang yang lalu-lalang akan menimbulkan peluang yang besar terhadap pembelian yang spontan, tanpa perencanaan, dan tanpa melalui usaha khusus; serta (b) kemacetan lalu lintas dapat menghambat pembelian.

4. Tempat parkir yang luas, nyaman, dan aman.

5. Ekspansi, yakni ketersediaan tempat yang luas untuk memungkinkan terjadinya ekspansi di masa mendatang.

6. Lingkungan, yakni area sekitar yang mendukung penawaran produk.

7. Persaingan, yakni mempertimbangkan cara untuk menunjukkan keunggulan dalam suatu persaingan.

8. Peraturan pemerintah, yakni pembangunan suatu bangunan harus sesuai dengan peraturan yang ada.

\section{Keragaman Produk}

Menurut Simamora (2000:441), keragaman produk adalah seperangkat lini produk dan unsur yang ditawarkan oleh seorang penjual kepada pembeli. Kotler dan Keller (2009) mendefinisikan keragaman produk sebagai kumpulan dari seluruh produk yang ditawarkan untuk dijual kepada pembeli.

Menurut Utami (2015), keragaman produk memiliki indikator sebagai berikut.

1. Variasi merek produk, yakni banyaknya merek produk yang ditawarkan,

2. Variasi kelengkapan produk, yakni sejumlah kategori produk yang berbeda di toko.

3. Variasi ukuran produk, yakni sejumlah standar ukuran produk yang tersedia di toko.

4. Variasi kualitas produk, yakni sejumlah standar kualitas umum yang berkaitan dengan cara produk memberikan manfaat.

\section{Kerangka Analisis}

Gambar berikut ini merupakan kerangka analisis dari penelitian ini. 


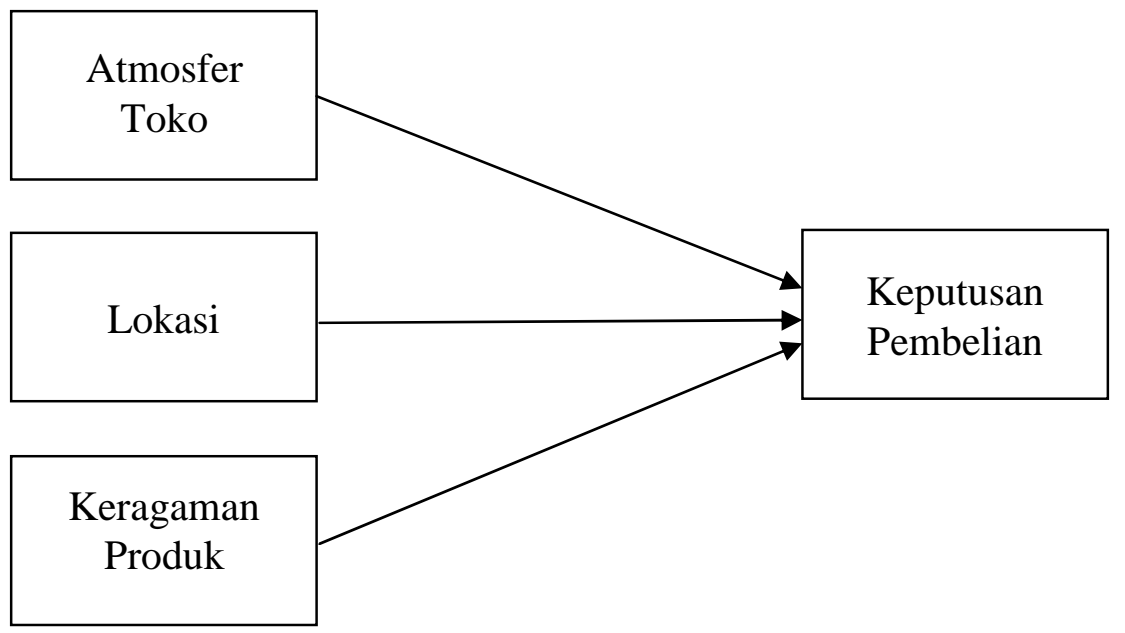

Gambar 1. Kerangka Analisis

\section{Keterkaitan Antarvariabel Penelitian}

\section{Keterkaitan antara Atmosfer Toko dan Keputusan Pembelian}

Hasil penelitian yang dilakukan oleh Hanafitrah dan Widiartanto (2018) serta Lisdayanti (2017) menunjukkan bahwa atmosfer toko berpengaruh positif dan signifikan terhadap keputusan pembelian. Sejalan dengan hal tersebut, Utami (2010) mengemukakan bahwa atmosfer toko ditujukan untuk merancang tanggapan emosional dan persepsi pelanggan, serta mempengaruhi pelanggan untuk membeli barang. Menurut Mowen dan Minor (2002:139), atmosfer toko dirancang untuk menciptakan suatu pengaruh tertentu. Dalam hal ini, pengaruh yang dimaksud merupakan pengaruh terhadap keputusan konsumen untuk melakukan pembelian atau tidak. Levy dan Weitz (2001:556) juga mengemukakan bahwa perilaku pembelian konsumen akan dipengaruhi oleh atmosfer toko.

$\mathrm{H}_{1}$ : Atmosfer toko berpengaruh positif dan signifikan terhadap keputusan pembelian pada Planet Ban Margonda Raya, Depok

\section{Keterkaitan antara Lokasi dan Keputusan Pembelian}

Menurut Swastha dan Irawan (2001), lokasi sangat mempengaruhi konsumen untuk melakukan pembelian. Suwarman (2011) juga mengemukakan bahwa lokasi berperan dalam memberikan pengaruh yang besar terhadap keinginan konsumen untuk datang dan berbelanja. Hal tersebut sejalan dengan hasil penelitian yang dilakukan oleh Lisdayanti (2017) dan Antari, dkk. (2014) yang menunjukkan bahwa lokasi berpengaruh positif dan signifikan terhadap keputusan pembelian. 
$\mathrm{H}_{2}$ : Lokasi berpengaruh positif dan signifikan terhadap keputusan pembelian pada Planet Ban Margonda Raya, Depok

\section{Keterkaitan antara Keragaman Produk dan Keputusan Pembelian}

Ogi, dkk. (2018) serta Prambudi dan Rachmi (2017) membuktikan bahwa keragaman produk berpengaruh positif dan signifikan terhadap keputusan pembelian. Hal tersebut menunjukkan bahwa semakin tinggi tingkat keragaman produk yang ditawarkan di suatu toko, maka semakin tinggi pula tingkat keputusan pembelian yang dilakukan terhadap produk yang ditawarkan di toko tersebut. Sebaliknya, semakin rendah tingkat keragaman produk yang ditawarkan di suatu toko, maka semakin rendah pula tingkat keputusan pembelian yang dilakukan terhadap produk yang ditawarkan di toko tersebut.

$\mathrm{H}_{3}$ : Keragaman produk berpengaruh positif dan signifikan terhadap keputusan pembelian pada Planet Ban Margonda Raya, Depok

\section{METODOLOGI PENELITIAN}

Data primer yang digunakan dalam penelitian ini berasal dari jawaban kuesioner yang diajukan responden. Data tersebut berjenis cross section. Populasi penelitian yang digunakan adalah pengguna jasa di Planet Ban Margonda Raya, Depok. Pengambilan sampel dilakukan dengan menggunakan metode accidental sampling dengan jumlah sampel sebanyak 100 responden. Jumlah sampel tersebut ditentukan berdasarkan rumus Anderson, et al. (2011). Analisis pengaruh setiap variabel independen terhadap variabel dependen dilakukan dengan menggunakan regresi linear berganda.

\section{HASIL PENELITIAN DAN PEMBAHASAN}

\section{Hasil Penelitian}

Instrumen penelitian ini dinyatakan valid dan reliabel karena telah memenuhi kriteria dalam uji validitas dan reliabilitas. Dalam penelitian ini, uji asumsi klasik dilakukan dengan menggunakan uji normalitas, heteroskedastisitas, multikolinearitas dan autokorelasi yang hasilnya menunjukkan bahwa data penelitian terdistribusi normal dan bebas dari masalah heteroskedastisitas, serta model regresi terbukti bebas dari masalah multikolinearitas dan autokorelasi.

Uji regresi linear berganda menghasilkan persamaan sebagai berikut.

$$
Y=0,311 X_{1}+0,498 X_{2}+0,147 X_{3}
$$


Keterangan:

$$
\begin{array}{ll}
\mathrm{Y} & =\text { Keputusan pembelian } \\
\mathrm{X}_{1} & =\text { Atmosfer toko } \\
\mathrm{X}_{2} & =\text { Lokasi } \\
\mathrm{X}_{3} & =\text { Keragaman produk }
\end{array}
$$

Model penelitian ini yang digunakan dalam penelitian ini juga dinyatakan layak terbukti layak berdasarkan hasil uji $\mathrm{F}$ karena atmosfer toko, lokasi dan keragaman produk secara simultan berpengaruh signifikan terhadap keputusan pembelian. Model regresi ini menghasilkan koefisien determinasi sebesar 0,558. Hal tersebut menunjukkan atmosfer toko, lokasi dan keragaman produk memberikan kontribusi sebesar 55,8\% dalam menjelaskan keputusan pembelian pada Planet Ban Margonda Raya, Depok.

Tabel berikut ini menunjukkan hasil pengujian terhadap hipotesis penelitian.

\section{Tabel 1. Hasil Pengujian Hipotesis}

\begin{tabular}{|l|c|c|c|}
\hline \multicolumn{1}{|c|}{ Variabel } & $\mathbf{T}_{\text {hitung }}$ & Signifikan & Kesimpulan \\
\hline Atmosfer toko & 4,113 & 0,000 & Positif dan signifikan \\
\hline Lokasi & 6,563 & 0,000 & Positif dan signifikan \\
\hline Keragaman produk & 2,071 & 0,041 & Positif dan signifikan \\
\hline
\end{tabular}

Berdasarkan tabel di atas, dapat dilihat bahwa atmosfer toko, lokasi dan keragaman produk secara parsial berpengaruh positif dan signifikan terhadap keputusan pembelian pada Planet Ban Margonda Raya, Depok.

\section{Pembahasan}

\section{Pengaruh Atmosfer Toko terhadap Keputusan Pembelian}

Hasil penelitian ini menunjukkan bahwa atmosfer toko berpengaruh positif dan signifikan terhadap keputusan pembelian pada Planet Ban Margonda Raya, Depok. Hal tersebut menunjukkan bahwa semakin baik atmosfer yang tercipta di suatu toko, maka semakin tinggi keputusan pembelian yang dilakukan terhadap produk yang ditawarkan di toko tersebut. Sebaliknya, semakin buruk atmosfer yang tercipta di suatu toko, maka semakin rendah keputusan pembelian yang dilakukan terhadap produk yang ditawarkan di toko tersebut. Hal tersebut sejalan dengan hasil penelitian yang dilakukan oleh Hanafitrah dan Widiartanto (2018) serta Lisdayanti (2017) yang menunjukkan bahwa atmosfer toko berpengaruh positif dan signifikan terhadap keputusan pembelian. 
Sejalan dengan hasil penelitian ini, Utami (2010) mengemukakan bahwa atmosfer toko memang ditujukan untuk merancang tanggapan emosional dan persepsi pelanggan, serta mempengaruhi pelanggan untuk membeli barang. Menurut Mowen dan Minor (2002:139), atmosfer toko didesain untuk menciptakan suatu pengaruh tertentu. Dalam hal ini, pengaruh yang dimaksud merupakan pengaruh terhadap keputusan konsumen untuk melakukan pembelian atau tidak. Levy dan Weitz (2001:556) juga mengemukakan bahwa perilaku pembelian konsumen dapat dipengaruhi oleh atmosfer toko. Menurut Kotler (2001:54) dalam Fahimah, dkk. (2015), atmosfer memberikan efek terhadap perilaku pembelian, yakni melalui penciptaan pengaruh yang akan berperan sebagai faktor situasional yang spesifik untuk membantu mengubah niat menjadi perilaku pembelian yang aktual.

\section{Pengaruh Lokasi terhadap Keputusan Pembelian}

Hasil penelitian ini menunjukkan bahwa lokasi berpengaruh positif dan signifikan terhadap keputusan pembelian pada Planet Ban Margonda Raya, Depok. Hal tersebut menunjukkan bahwa semakin strategis lokasi suatu toko, maka semakin tinggi keputusan pembelian yang dilakukan terhadap produk yang ditawarkan di toko tersebut. Sebaliknya, semakin tidak strategis lokasi suatu toko, maka semakin rendah keputusan pembelian yang dilakukan terhadap produk yang ditawarkan di toko tersebut. Hal tersebut sejalan dengan temuan Lisdayanti (2017) dan Antari, dkk. (2014) yang menunjukkan bahwa lokasi memiliki pengaruh yang positif dan signifikan terhadap keputusan pembelian.

Swastha dan Irawan (2001) mengemukakan bahwa lokasi sangat mempengaruhi konsumen untuk melakukan pembelian. Menurut Suwarman (2011), lokasi akan memberikan pengaruh yang besar terhadap keinginan konsumen untuk datang dan berbelanja. Oleh karena itu, Alma (2003:105) mengemukakan bahwa pemilihan lokasi usaha yang tepat akan menentukan keberhasilan usaha di masa mendatang. Lokasi yang strategis akan mudah diakses oleh konsumen sehingga akan meningkatkan probabilitas terciptanya keputusan pembelian. Selain itu, toko yang berada di lokasi yang visible dalam jarak pandang normal juga akan memungkinkan konsumen untuk menemukan toko yang bersangkutan dengan mudah, sehingga akan meningkatkan probabilitas terciptanya keputusan pembelian. 


\section{Pengaruh Keragaman Produk terhadap Keputusan Pembelian}

Hasil penelitian ini menunjukkan bahwa keragaman produk berpengaruh positif dan signifikan terhadap keputusan pembelian pada Planet Ban Margonda Raya, Depok. Hal tersebut menunjukkan bahwa semakin tinggi tingkat keragaman produk yang ditawarkan di suatu toko, maka semakin tinggi pula tingkat keputusan pembelian yang dilakukan terhadap produk yang ditawarkan di toko tersebut. Sebaliknya, semakin rendah tingkat keragaman produk yang ditawarkan di suatu toko, maka semakin rendah pula tingkat keputusan pembelian yang dilakukan terhadap produk yang ditawarkan di toko tersebut. Hal tersebut sejalan dengan temuan Ogi, dkk. (2018) serta Prambudi dan Rachmi (2017) yang membuktikan bahwa keragaman produk berpengaruh positif dan signifikan terhadap keputusan pembelian.

Pengaruh positif signifikan yang dimiliki oleh keragaman produk terhadap keputusan pembelian timbul karena keragaman produk akan menyediakan alternatif yang lebih beragam bagi konsumen, sehingga akan memungkinkan konsumen tersebut untuk memilih keputusan pembelian yang terbaik dari seperangkat alternatif yang tersedia sesuai dengan kebutuhan dan keinginannya, baik dari segi merek, lini produk, ukuran, maupun standar kualitas. Oleh karena banyaknya pilihan yang tersedia, maka kemungkinan konsumen untuk memperoleh produk yang sesuai dengan kebutuhan dan keinginannya pun menjadi semakin tinggi, sehingga probabilitas terciptanya keputusan pembelian pun ikut meningkat.

\section{KESIMPULAN DAN SARAN}

\section{Kesimpulan}

Berdasarkan hasil dari penelitian ini, dapat disimpulkan hal-hal sebagai berikut.

1. Atmosfer toko berpengaruh positif dan signifikan terhadap keputusan pembelian pada Planet Ban Margonda Raya, Depok.

2. Lokasi berpengaruh positif dan signifikan terhadap keputusan pembelian pada Planet Ban Margonda Raya, Depok.

3. Keragaman produk berpengaruh positif dan signifikan terhadap keputusan pembelian pada Planet Ban Margonda Raya, Depok.

\section{Saran}

Berdasarkan hasil penelitian dan kesimpulan yang telah dikemukakan, berikut ini dikemukakan beberapa saran bagi pihak-pihak yang bersangkutan. 
1. Planet Ban perlu senantiasa memastikan bahwa tokonya memiliki atmosfer yang baik, yakni dengan lebih memperhatikan layout penataan barang yang rapih.

2. Apabila Planet Ban hendak membuka toko baru di area yang baru, maka lokasi toko hendaknya dipertimbangkan dengan matang untuk memastikan bahwa toko yang bersangkutan berada di lokasi yang strategis dan visible.

3. Planet Ban diharapkan dapat senantiasa menyediakan produk yang beragam, baik dari segi jenis, merek, maupun variasi ukuran dan kualitas produk.

\section{DAFTAR PUSTAKA}

Alma, B. 2003. Manajemen Pemasaran dan Pemasaran Jasa. Alfabeta. Bandung.

Anderson, D.R., D.J. Sweeney dan T.A. Williams. 2011. Statistics for Business and Economics. Eleventh Edition. Cengage Learning. Boston.

Antari, K.R.M., K. Dunia dan L. Indrayani. 2014. Pengaruh Lokasi dan Harga terhadap Keputusan Berbelanja pada Mini Market Sastra Mas Tabanan. Jurnal Pendidikan Ganesha. 4(1): 1-11.

Berman, B. dan J.R. Evans. 2004. Retail Management: A Strategic Approach. Ninth Edition. Prentice Hall. New Jersey.

Bruner, G.C. 1990. Music, Mood and Marketing. Journal of Marketing. 54(4): 94-104.

Fahimah, A. Fauzi dan K. Hidayat. 2015. Pengaruh Store Atmosphere terhadap Keputusan Pembelian: St=urvei pada Pengunjung di Madam Wang Secret Garden Cafe Malang. Jurnal Administrasi Bisnis. 28(2): 1-10.

Hanafitrah, A. dan Widiartanto. 2018. Pengaruh Kualitas Produk, Store Atmosphere dan Discount terhadap Keputusan Pembelian Distro House of Smith Semarang. Jurnal Ilmu Administrasi Bisnis. 7(1): 1-12.

Kotler, P. 2001. Atmospherics as a Marketing Tool. Journal of Retailing. 49(4): 48-64. . dan K.L. Keller. 2008. Marketing Management. $13^{\text {th }}$ Edition. Prentice Hall. New Jersey. Terjemahan B. Sabran. 2009. Manajemen Pemasaran. Edisi 13. Erlangga. Jakarta.

dan G. Armstrong. 2007. Principles of Marketing. $12^{\text {th }}$ Edition. Prentice Hall. New Jersey. Terjemahan D. Sihombing. 2008. Prinsip-prinsip Pemasaran. Edisi 12. Erlangga. Jakarta.

Levy, M. Dan B.A. Weitz. 2001. Retailing Management. Fourth Edition. McGraw-Hill. New York. 
Lisdayanti, A. 2017. Pengaruh Lokasi, Store Atmosphere, Harga dan CRM terhadap Keputusan Pembelian Konsumen pada the Milk Bar Bandung. Sustainable Competitive Avantage. 7: 169-187.

Mowen, J.C. dan M. Minor. 1997. Consumer Behavior. $5^{\text {th }}$ Edition. Prentice Hall. New Jersey. Terjemahan D.K. Yahya. 2002. Perilaku Konsumen. Edisi Kelima. Erlangga. Jakarta.

Ogi, Y., A. Supandi dan J. Rotinsulu. 2018. Pengaruh Kualitas Pelayanan, Keragaman Produk dan Citra terhadap Keputusan Pembelian di Matahari Mega Mall Manado. Jurnal EMBA. 6(4): 3953-3962.

Planet Ban. 2018. https://www.planetban.com/. 3 Januari 2018 (23:18).

Prambudi, Y. dan A. Rachmi. 2017. Pengaruh Store Atmosphere dan Keragaman Produk terhadap Keputusan Pembelian di Cap Jempol Ponsel Malang. Jurnal Aplikasi Bisnis. 3(1): 80-85.

Schiffman, L.G., dan L.L. Kanuk. 2000. Consumer Behavior. $7^{\text {th }}$ Edition. Prentice Hall. New Jersey. Terjemahan Z. Kasip. 2008. Perilaku Konsumen. Edisi Ketujuh. Indeks. Jakarta.

Simamora, H. 2000. Manajemen Pemasaran Internasional. Cetakan Pertama. Salemba Empat. Jakarta.

Suwarman, U. 2011. Perilaku Konsumen: Teori dan Penerapannya dalam Pemasaran. Edisi 2. Ghalia Indonesia. Bogor.

Swastha, B. dan Irawan. 2001. Manajemen Pemasaran Modern. Liberty. Yogyakarta.

Tjiptono, F. 2009. Strategi Pemasaran. Edisi Kedua. Cetakan Ketujuh. Andi. Yogyakarta.

Top Brand Award. 2018. Top Brand Index 2016 Fase 2 Kategori Retail. https://www.topbrand-award.com/top-brand-survey/survey-result/top_brand_index 2016_fase_2. 3 Januari 2018 (22:10).

Top Brand Award. 2018. Top Brand Index 2017 Fase 2 Kategori Retail. https://www.topbrand-award.com/top-brand-survey/survey-result/top_brand_index 2017_fase_2. 15 Fabruari 2018 (21:49).

Utami , C.W. 2010 . Manajemen Ritel: Strategi dan Implementasi Operasional Bisnis Ritel Modern di Indonesia. Edisi Kedua. Salemba Empat. Jakarta.

. 2015 . Manajemen Ritel: Strategi dan Implementasi Operasional Bisnis Ritel Modern di Indonesia. Edisi Ketiga. Salemba Empat. Jakarta. 